\title{
LAJU PERCEPATAN PERKEMBANGAN PERBANKAN SYARIAH MELALUI PENERAPAN TATA KELOLA SYARIAH
}

\author{
Rachmad Nor Firman \\ STAI Shalahuddin Pasuruan \\ rachmadfirman2@gmail.com
}

\begin{abstract}
Indonesian sharia banking industry's growth chart shows a rising, albeit decelerating. Islamic banking accounted for $4.81 \%$ of market share to achievethe growth assets $11.97 \%$ as of June 2018. At the global level, the Islamic financial services sector including banking, control of 3\% and together with Qatar, Saudi Arabia, Malaysia, United Arab Emirates and Turkey the driving force of Islamic finance in the future. One of the strategic issues that are a barrier is a public misperception of the Islamic banking, either on contract, products and services that are considered not compliant with Islamic principles. Implementation of governance is an effort to accelerate the growth of Islamic banking.
\end{abstract}

Keywords: Islamic Banking, Governance, Acceleration of Growth

\section{Pendahuluan}

Salah satu isu strategis perbankan syariah di Indonesia adalah pertumbuhannya yang berjalan lambat, apabila dibandingkan dengan potensi pangsa pasar yang sangat besar, mengingat Indonesia adalah negara dengan mayoritas penduduk muslim terbesar. Saat ini, pangsa pasar perbankan syariah baru mencapai 4,81\% atau kurang dari $5 \%$ dengan total aset sebesar Rp. 306,23 Triliun per Juni $2018^{1}$. Di sisi lain, peluang Indonesia untuk menjadi pendorong industri keuangan syariah global terbuka lebar, mengingat saat ini Indonesia secara internasional dipandang sebagai kekuatan dan memiliki potensi besar keuangan syariah global, yakni salah satu diantara 10 negara terbesar di bidang keuangan syariah, bersama Malaysia, Arab Saudi, Iran, UEA, Kuwait, Qatar, Bahrain, Turki dan Bangladesh. Menyadari potensi tersebut, pemerintah melalui BAPPENAS telah meluncurkan Master Plan Arsitektur Keuangan Syariah Indonesia dan telah memasukkan keuangan syariah dalam arus utama strategi nasional yang akan membantu pemerintah mencapai tujuan pembangunan. Master plan ini bertujuan untuk meningkatkan infrastruktur dan

\footnotetext{
${ }^{1}$ Nurhisam Luqman, Kepatuhan Syariah (Sharia Compliance) Dalam Industri Keuangan Syariah, (Jurnal Hukum IUS QUIA IUSTUM, 2016) Vol.23 No.1, 78.
} 
kemampuan sistem keuangan syariah, mengatasi kesenjangan yang ada, memperbaiki kinerja kelembagaan, menciptakan peluang baru di pasar dosestik dan internasional dan memposisikan Indonesia sebagai pemain utama dalam keuangan syariah di dunia. ${ }^{2}$

Salah satu hambatan utama dalam pertumbuhan industri keuangan syariah, khusunya perbankan adalah kurangnya transparansi dan tata kelola yang baik. Tidak optimalnya transparansi dan tatakelola ini terlihat dalam beberapa isu strategis antara lain : produk yang tidak variatif dan pelayanan yang belum sesuai dengan ekspektasi masyarakat; kuantitas dan kualitas sumber daya manusia yang belum memadai; pemahaman dan kesadaran masyarakat yang masih rendah sehingga menimbulkan mispersepsi masyarakat berkaitan dengan istilah, akad dan produk; pandangan bahwa perbankan syariah berbiaya mahal, serta pengaturan dan pengawasan yang belum optimal. Pandangan keliru tersebut dapat diatasi melalui implementasi tatakelola yang baik pada perbankan syariah.

Perbankan syariah merupakan bagian dari sektor jasa keuangan yang dalam aktivitasnya, khususnya produk, akad dan layanannya, selain bertumpu pada prinsip kehati-hatian (prudential banking principles) juga wajib mematuhi prinsip syariah $^{3}$. Berdasarkan Pasal 1 Angka 7 UU No: 21 tahun 2008 Tentang Perbankan Syariah (UU Perbankan Syariah), yang dimaksud dengan Bank syariah adalah bank yang menjalankan kegiatan usahanya berdasarkan prinsip syariah dan menurut jenisnya terdiri atas Bank Umum Syariah (BUS) dan Bank Pembiayaan Rakyat Syariah (BPRS). Bank umum syariah adalah Bank syariah yang dalam kegiatannya memberikan jasa dalam lalu lintas pembayaran; sedangkan BPRS adalah Bank syariah yang dalam kegiatannya tidak memberikan jasa dalam lalu lintas pembayaran. Selain itu, UU Perbankan mengenal Unit Usaha Syariah (UUS) yaitu unit kerja dari kantor pusat Bank Umum Konvensional yang berfungsi sebagai kantor induk dari kantor atau unit

2 BAPPENAS, Masterplan Arsitektur Keuangan Syariah Indonesia, Cetakan Kedua (Jakarta: BAPPENAS, 2018), 3.

${ }^{3}$ Berdasarkan Pasal 1 Angka 12 UU No : 21 Tahun 2008 tentang Perbankan Syariah, yang dimaksud dengan Prinsip Syariah adalah "prinsip hukum Islam dalam kegiatan Perbankan berdasarkan Fatwa yang dikeluarkan oleh lembaga yang memiliki kewenangan dalam penetapan fatwa di bidang syariah". 
yang melaksanakan kegiatan usaha berdasarkan prinsip syariah, yaitu prinsip hukum Islam berdasarkan Fatwa yang dikeluarkan oleh lembaga yang memiliki kewenangan dalam penetapan Fatwa di bidang syariah. ${ }^{4}$ Dengan demikian, berdasarkan sistem hukum Indonesia, Fatwa yang dikeluarkan oleh Dewan Syariah Nasional (DSN) merupakan sumber hukum dalam pembentukan regulasi perbankan syariah, khususnya bagi Otoritas Jasa Keuangan (OJK) dan Bank Indonesia dalam menerbitkan peraturan. Implementasi prinsip syariah inilah yang menjadi pembeda antara perbankan konvensional dan perbankan syariah. Selain itu, Pasal 34 UU Perbankan Syariah mewajibkan penerapan tata kelola yang baik dalam menjalankan kegiatan usahanya. Dalam perspektif hukum keuangan Islam, tata kelola berbasis prinsip syariah ini wajib diimplemntasikan untuk memastikan kepatuhan terhadap prinsip syariah. Hal ini dikemukakan dalam working group yang diselenggarakan oleh Islamic Financial Services Board (IFSB) ${ }^{5}$ bahwa konsep governance tidak hanya berkaitan dengan pertanggungjwaban terhadap sesama manusia, namun pada akhirnya pertanggungjawaban kepada Allah ${ }^{6}$.

Aktivitas perbankan syariah tidak hanya berlandaskan pada kontrak dan peraturan perundang- undangan, namun tunduk pada pedoman dan etika yang diturunkan dari Al Quran, antara lain kejujuran, dapat dipercaya (amanah), perolehan pendapatan yang tidak berasal dari penipuan atau kecurangan, dan tindakan-tindakan yang tidak patut. Dalam tataran perbankan global, prinsip dan etika yang bersumber pada prinsip syariah tersebut dielaborasi dalam pedoman tentang good corporate governance yang dikeluarkan oleh Organisation for Economic Co-operation and Development (OECD) dan Bank for International Settlement (BIS) yang juga menjadi acuan bagi perbankan syariah. Setidaknya terdapat 5 elemen penting dalam tatakelola berdasarkan prinsip syariah, yaitu: good board practices; control environment and

\footnotetext{
${ }^{4}$ Lembaga yang berwenang menetapkan Fatwa adalah Dewan Syariah Nasional (DSN)-Majelis Ulama Indonesia (MUI).

${ }^{5}$ Islamic Financial Services Board (IFSB), is an international standard setting body of regulatory and supervisory agencies that have vested interest in ensuring the soundness and stability of the Islamic financial services (IFS) industry.

${ }^{6}$ Madzlan Mohamad Hussain, Corporate Governance Of Institutions Offering Islamic Financial Services (IIFS): An insight of the Islamic Financial Services Board's Initiatives (Aman Jordan: IIFS, 2005), 10
} 
processes; disclosure and transparency; shareholder rights dan commitment ${ }^{7}$.

Berdasarkan garis besar dari pedoman yang dikeluarkan oleh OECD, tata kelola sektor jasa keuangan Islam menekankan pada pentingnya accountability, transparency and trustworthines ${ }^{8}$.Pada tahun 2015 telah dilakukan pertemuan G20 Finance Ministers and Central Bank Governor yang menggagas adanya revisi prinsip-prinsip Good Corporate Governance. Prinsip-prinsip tersebut tertuang melalui beberapa rekomendasi yang dikeluarkan G20/OECD yaitu: peran kerangka kerja untuk mendorong pasar yang wajar dan terbuka; hak dan perlakuan yang sama bagi pemegang saham; pemenuhan insentif yang baik bagi investor dan lembaga lainnya; peran pemangku kepentingan serta keterbukaan dan transparansi.

Berdasarkan guidelines yang telah dikemukakan diatas, dapat disimpulkan bahwa prinsip tata kelola yang diatur dalam PBI 11/33/PBI/2009 Tentang Pelaksanaan Good Corporate Governance bagi Bank Umum Syariah dan Unit Usaha Syariah pada dasarnya sudah mengikuti standar Internasional, hanya saja "trustworthy" tidak secara eksplisit muncul dalam prinsip tata kelola Indonesia. Pada dasarnya, trustworthy melekat pada fungsi perbankan sebagai agent of trust, mengingat kegiatan bank bertumpu pada adanya kepercayaan masyarkat. Mengacu pada PBI tersebut, tatakelola pada Bank Umum Syariah (BUS) dan Unit Usaha Syariah (UUS) wajib menerapkan prinsip keterbukaan (transparency), akuntabilitas (accountability), pertanggungjawaban (responsibility), profesional (professional) dan kewajaran (fairness). ${ }^{9}$ Selanjutnya, pelaksanaan tata kelola tersebut wajib memenuhi prinsip-prinsip syariah sebagaimana ditetapkan dalam undang-undang Perbankan syariah, yaitu kegiatan usaha yang tidak mengandung unsur riba,maysir, gharar,haram dan zalim $^{10}$.

\footnotetext{
${ }^{7}$ Jahanara Sajjad Ahmad, Corporate Governance in Islamic Banks, Hawkamah The Institute for corporate governance. (2010), 3.

${ }^{8}$ Nasser Saidi, Corporate Governance in Islamic Finance, Hawkamah, the institute for corporate Governance, 434

${ }^{9}$ Lihat Pasal 1 Angka 10 PBI 11/33/PBI/2009 Tentang Pelaksanaan Good Corporate Governance bagi Bank Umum Syariah dan Unit Usaha Syariah.

${ }^{10}$ Rincian dari 5 prinsip syariah tersebut dapat dilihat dalam Penjelasan Pasal 2 UU No : 21 Tahun 2008 Tentang Perbankan Syariah
} 
Pelaksanaan tata kelola yang baik dalam industri perbankan syariah merupakan salah satu upaya untuk melindungi kepentingan stakeholders dan meningkatkan kepatuhan terhadap peraturan perundang-undangan yang berlaku serta nilai-nilai etika yang berlaku secara umum serta prinsip syariah. Berdasarkan sistem hukum Indonesia, prinsip-prinsip syariah yang terkandung dalam Qur'an dan hadist ini diterjemahkan dalam Fatwa yang dikeluarkan oleh DSN, yang selanjutnya menjadi sumber dalam pembentukan perundangundangan yang mengatur aktivitas keuangan syariah di Indonesia. Berdasarkan permasalahan yang telah diuraikan, penelitian ini bertujuan untuk mengkaji urgensi penerapan tatakelola perusahaan berdasarkan prinsip syariah (sharia good governance) guna meningkatkan kepercayaan masyarakat dan mengubah persepsi yang keliru tentang perbankan syariah, yang pada gilirannya dapat mendorong percepatan pertumbuhan perbankan syariah di Indonesia.

Berdasarkan latar belakang permasalahan yang telah diuraikan, dapat diidentifikasi permasalahan utama yang akan dikaji dan dianalisa, yaitu bagaimana implementasi tata kelola berdasarkan prinsip syariah sebagai upaya untuk mempercepat pertumbuhan perbankan syariah di Indonesia.

\section{Metode Penelitian}

Penelitian ini menggunakan metode penelitian yang bersifat deskriptif analitis yaitu menggambarkan dan menganlisis data yang diperoleh berdasarkan data sekunder, baik bahan hukum primer, sekunder dan tersier. Sedangkan metode pendekatan yang digunakan adalam yuridis normatif, yang lebih menitikberatkan pada studi kepustakaan, yang selanjutnya dianalisa secara yuridis kualitatif.

\section{Hasil Penelitian Dan Pembahasan}

1. Beberapa Perbedaan Mendasar Antara Perbankan Syariah Dan Perbankan Konvensional

Sebagaimana telah diuraikan sebelumnya, bahwa salah satu isu strategis yang menjadi hambatan tumbuh kembang perbankan syariah adalah mispersepsi masyarakat terhadap praktik perbankan syariah, yang 
dianggap tidak berbeda dengan konvensional. Dalam praktik, aktivitas yang dilakukan oleh bank syariah, belum sepenuhnya mematuhi prinsipprinsip syariah. Contoh sederhana dalam praktik misalnya, dalam pembiayaan perumahan melalui akad Musyarakah Mutanaqisah (MMQ) atau akad Murabahah, bank seharusnya terlebih dahulu memiliki properti/aset yang menjadi objek kontrak. Selama itu tidak dapat dibuktikan sulit menyebutkan bahwa kontrak tersebut adalah kontrak pembiayaan perumahan berdasarkan prinsip syariah. Beberapa pertanyaan seperti "mengapa bertransaksi di perbankan syariah justru biayanya lebih mahal?", atau “mengapa dalam transaksi perbankan syariah, persentase keuntungan telah ditetapkan di awal?, menunjukkan bagaimana pandangan masyarakat tentang perbankan syariah. Diperlukan pemahaman yang utuh untuk dapat memberikan jawaban yang memuaskan dan memberikan pengertian bagaimana hal itu dapat terjadi. Oleh karena itu diperlukan berbagai upaya untuk memberikan pemahaman yang komprehensif dan benar mengenai perbedaan antara perbankan syariah dan konvensional, salah satunya melalui peningkatan kuantitas dan kualitas sumber daya manusia yang kompeten tentang perbankan syariah, khususnya untuk mewujudkan visi perbankan syariah Indonesia yang berkontribusi signifikan bagi pertumbuhan ekonomi berkelanjutan, pemerataan pembangunan dan stabilitas sistem keuangan serta berdaya saing tinggi ${ }^{11}$ Pemahaman tentang aktivitas perbankan syariah yang komprehensif antara lain dengan terlebih dahulu mengenali perbedaan antara bank syariah dan bank konvensional, yang mencakup 3 level, yaitu : conceptual and socio-religious level; business model and governing framework level; dan product implementation model. Berikut adalah perbedaan kunci antara bank syariah dan konvensional $^{12}$

${ }^{11}$ Roadmap Syariah Indonesia 2015-2019, 17.

${ }^{12}$ Ethica Institute of Islamic Finance, Handbook of Islamic Finance, 2017 Edition. 
a. Level konseptual dan socio-religious

Perbankan Islam (syariah) tidak bertumpu pada pinjam meminjam uang, melainkan pada perdagangan dan investasi, sedangkan perbankan konvensional berbasis pinjam meminjam berbasis bunga. Selain itu, perbankan syariah bekerja berdasarkan pedoman sosio-religius yang melarang riba, transaksi spekulatif dan jual beli utang, sedangkan dalam aktivitas perbankan konvensional tidak ada larangan sosio-religius, mengingat bunga merupakan tulang punggung dalam sistem konvensional. Selanjutnya, perbankan syariah tidak mengizinkan pembiayaan untuk industri yang dilarang berdasarkan prinsip syariah atau yang berbahaya bagi masyarakat. Perbankan konvensional dapat membiayai semua jenis industri kecuali yang dilarang oleh peraturan perundang- undangan.

b. Level model bisnis dan kerangka kerja;

Model bisnis perbankan syariah berbasis perdagangan, sehingga terlibat secara aktif dalam proses dan aktivitas produksi, sedangkan dalam perbankan konvensional, bank tidak terlibat dalam aktivitas, kecuali sebagai kreditor. Selain itu, perbankan syariah memerlukan persetujuan dari Dewan Pengawas Syariah untuk akad, produk dan jasa untuk memastikan kepatuhan terhadap prinsip syariah.

c. Level implementasi produk;

Produk perbankan syariah harus bertumpu pada aset riil, sewa menyewa aset dan kerjamasama berdasarkan pembagian untungrugi, sedangkan perbankan konvensional memperlakukan uang sebagai objek transaksi. Perbankan syariah dapat mempertimbangkan pinjam meminjam non komersial dan harus bebas dari bunga, sedangkan perbankan konvensiobal sebagian besar produknya berbasis pinjaman.

Mengacu pada perbedaan di atas, maka dapat dilihat bahwa hubungan antara bank dan nasabah pada bank konvensional adalah 
hubungan antara kreditor dan debitor, dan keuntungan baik bagi bank maupun customer bergantung pada naik turunnya suku bunga, sedangkan dalam bank Islam, hubungan antara bank dan nasabah berdasarkan model pembiayaan dan sifat fasilitas yang diberikan. Selanjutnya, peran bank dan nasabah antara bank syariah dan bank konvensional dapat dilihat dalam tabel di bawah ini:

\begin{tabular}{lllll} 
& Bank Konvensional & \multicolumn{2}{c}{ Bank Islam } \\
& $\begin{array}{c}\text { Peran } \\
\text { (Bank }- \\
\text { Nasabah) }\end{array}$ & Kompensasi & $\begin{array}{c}\text { Peran } \\
\text { (Bank - Nasabah) }\end{array}$ & Kompensasi \\
\hline $\begin{array}{l}\text { Penempatan } \\
\text { (simpanan) }\end{array}$ & $\begin{array}{l}\text { Debitor } \\
\text { Kreditor }\end{array}$ & - Bunga & $\begin{array}{l}\text { Mudharib - sahib al } \\
\text { mal }\end{array}$ & $\begin{array}{l}\text { Keuntungan } \\
\text { dari bagi hasil }\end{array}$ \\
\hline Pembiayaan & & Bunga & $\begin{array}{l}\text { Penjual - Pembeli } \\
\text { Yang menyewakan }\end{array}$ & $\begin{array}{l}\text { Harga } \\
\text { Sewa } \\
\end{array}$ \\
& & & $\begin{array}{l}\text { Penyewa } \\
\text { Mitra }\end{array}$ & Keuntungan \\
& & & Komisi \\
& & & &
\end{tabular}

Sumber : Ethica Institute, Handbook of Islamic Finance, 2018

Berdasarkan tabel di atas, bank konvensional memperoleh kompensasi hanya dari bunga, tanpa mempertimbangkan risiko, sebagaimana menjadi prinsip dalam aktivitas bank syariah, yaitu "no gain can be without risk". Dengan memahami perbedaan karakteristik antara bank konvensional, dapat diketahui bahwa diperlukan upaya untuk dapat memberikan pemahaman pada masyarakat, sehinggap mispersepsi dapat diminimalisasi dan selanjutnya kepercayaan masyarakat terhadap bank syariah akan meningkat. Dalam tataran praktis, prinsip-prinsip syariah ini akan menjelma dalam implementasi tata kelola yang baik.

\section{Tata Kelola yang Baik (good governance) pada Perbankan Syariah.}

Tata kelola yang baik bagi perbankan syariah tentu berbeda dengan tata kelola bank konvensional, karena tujuan akhir dari aktivitas bank syariah tidak dapat dilepaskan dari maqasid syariah, yaitu tujuan utama yang ingin diwujudkan oleh syariah, yaitu "obligation of the shariah is to provide the well being of all humankind. 
Which lies in safeguarding their faith, their human self (nafs), their intellect (aql), their progeny (nasl) and thir wealth (mal) ${ }^{13}$ Penerapan tata kelola yang baik, konsisten dan berkelanjutan selain bertujuan untuk melindungi kepentingan stakeholders, juga meningkatkan kepatuhan terhadap prinsip syariah. Kepatuhan terhadap prinsip syariah ini yang akan menjadi pembeda antara lingkup, urgensi, dan penerapan tata kelola di perbankan syariah. Prinsip syariah ini selanjutnya akan terlihat dari prinsip dasar operasional perbankan syariah dimana modal bank dan simpanan disalurkan melalui transaksi pembiayaan berbasis bagi hasil, komisi dan marjin. Selain itu, bank syariah memiliki fungsi sosial sebagai penampung dana zakat dan juga pemberi pinjaman kebajikan/ dana talangan (qard dan qardulhasan) yang tidak dikenal dalam perbankan konvensional. Dari sisi tujuan, prinsip syariah mencirikan karakteristik yang lebih mengedepankan kesejahteraan umat dan terciptanya pertumbuhan berkelanjutan dengan fokus pada sektor riil yang menciptakan nilai tambah. Itu sebabnya sistem governance pada perbankan syariah dianggap lebih kompleks daripada perbankan konvensional karena selain harus memperhatikan regulasi secara umum, juga harus mematuhi prinsip syariah yang berasal dari hukum Islam untuk dapat berkompetisi dalam pasar. ${ }^{14}$ Sebagai bagian dari sistem perbankan syariah, tata kelola perbankan syariah di Indonesia akan sangat dipengaruhi oleh sistem hukum Indonesia yang lebih dipengaruhi oleh sistem hukum civil law, dimana peraturan perundang-undangan menjadi sumber utama, sehingga prinsip syariah yang tertuang dalam Fatwa DSN harus terlebih dahulu diterjemahkan ke dalam hukum positif, khususnya peraturan yang dikeluarkan oleh otoritas jasa keuangan baik OJK maupun Bank Indonesia. Kerjasama ke dua otoritas ini diperlukan untuk menghindari duplikasi dan saling melengkapi pengaturan

\footnotetext{
${ }^{13}$ Mehmet Asutay, An Introduction to Islamic Moral Economy, Durham Islamic Finance Summer School 2013, (Durham, UK, 2013)

${ }^{14}$ Frederick V.Perry, The Corporate Governance of Islamic Banks : A Better Way of Doing

Business?, (Michigan State: Journal of International Law, 2018) Vol.19:2, 266.
} 
perbankan syariah khususnya ${ }^{15}$.

\section{Implementasi Shariah Governance Sebagai Upaya Meningkatkan Pertumbuhan Perbankan Syariah}

Pertumbuhan perbankan syariah tidak dapat dilepaskan dari keberhasilannya menjalankan fungsinya sebagai agent of services dan agent of trust. Menjaga dan meningkatkan kepercayaan masyarakat terhadap produk dan layanan perbankan yang patuh terhadap prinsip syariah merupakan salah satu cara untuk mempercepat pertumbuhan perbankan syariah. Isu strategis berupa mispersepsi dan rendahnya tingkat kepercayaan masyarakat terhadap perbankan syariah dapat diubah melalui implementasi kebijakan perbaikan kuantitas dan kualitas sumber daya manusia. Sumber daya manusia yang kompeten merupakan implementasi prinsip akuntabilitas, yang mengandung unsur kejelasan fungsi dalam organisasi dan cara mempertanggungjawabkannya. Pelaku perbankan syariah harus dapat mempertanggungjawabkan kinerjanya secara transparan dan wajar. Untuk itu bisnis syariah harus dikelola secara benar, terukur dan sesuai dengan stakeholder. Selain itu, akuntabilitas merupakan prasyarat yang diperlukan untuk mencapai bisnis yang berkesinambungan. Berdasarkan pemikiran tersebut, maka diperlukan hal sebagai berikut :

a. Perbankan syariah harus memiliki sumber daya manusia yang menguasai prinsip syariah untuk memastikan bahwa aktivitas, produk, dan layanan perbankan patuh terhadap prinsip syariah;

b. Menetapkan kewajiban dan tanggung jawab setiap sumber daya manusia secara jelas.

Selanjutnya, untuk mengimbangi profesionalisme sumber daya manusia, baik otoritas maupun perbankan syariah wajib melakukan edukasi melalui peningkatan literasi dan preferensi masyarakat, serta penyediaan informasi yang jelas, sehingga terdapat pengetahuan yang seimbang dan selaras antara bank syariah sebagai institusi dan masyarakat. Kegiatan ini sejalan dengan makna yang terkandung dalam

${ }^{15}$ Otoritas Jasa Keuangan, Booklet Perbankan Indonesia, Edisi 3 (Jakarta: OJK, 2016), 5. 
prinsip transparansi, yaitu adanya unsur pengungkapan dan penyediaan informasi yang mudah diakses oleh seluruh pemangku kepentingan. Transparansi sangat diperlukan bagi perbankan syariah agar dapat menjalankan kegiatannya secara objektif dan sehat. Transparansi disini berarti perbankan syariah mempunyai kewajiban :

a. Menyediakan informasi tepat waktu, memadai, jelas, akurat serta mudah diakses oleh semua pemangku kepentingan sesuai dengan haknya.

b. Tidak mengurangi kewajiban bank syariah untuk memenuhi kewajiban kerahasiaan bank, rahasia jabatan dan perlindungan hak pribadi.

c. Menyediakan pedoman prilaku yang telah disepakati;

d. Meyakini bahwa semua prosedur, akad, produk dan layanan telah sesuai dengan prinsip syariah yaitu halal, tayib ikhsan dan tawazun.

Selanjutnya, selain mengubah persepsi dan meningkatkan kepercayaan masyarakat, untuk menjaga pertumbuhan, perbankan syariah wajib menerapkan prinsip responsibilitas untuk menjaga keberlanjutan usaha dan mendapat pengakuan sebagai pelaku bisnis yang baik. Oleh karena itu, bank syariah perlu melakukan hal berikut :

a. Berpegang pada prinsip kehati-hatian dan memastikan kepatuhan terhadap prinsip syariah dan peraturan perundang-undangan, serta peraturan internal bank.

b. Melaksanakan akad yang telah dibuat;

c. Melaksanakan tanggung jawab sosial, khususnya terhadap lingkungan dan masyarakat setempat melalui zakat, infaq dan sadaqah.

Selanjutnya, melalui penerapan prinsip independensi, perbankan syariah diharapkan dapat istiqamah, berpegang teguh pada kebenaran dan tidak dapat di intervensi oleh pihak manapun, sehingga dapat memberikan jaminan bagi masyarakat bahwa dalam melakukan kegiatannya, senantiasa memperhatikan kepentingan seluruh 
stakeholder, melalui implementasi good corporate governance, mispersepsi dapat diubah, kepercayaan masyarakat dapat ditingkatkan, dan tujuan prinsip syariah untuk menciptakan kesejahteraan dan bisnis yang berkelanjutan dapat dicapai. Terakhir, implementasi prinsip kewajaran dan kesetaraan mengandung unsur kesamaan perlakuan, dan manisfestasi adil dalam dunia bisnis. Dalam melaksanakan kegiatannya, perbankan syariah harus memperhatikan kepentingan pemangku kepentingan.

Salah satu yang membedakan perbankan syariah dengan perbankan konvensional adalah kewajiban Bank syariah dan Bank konvensional yang memiliki Unit Usaha Syariah untuk membentuk Dewan Pengawas Syariah (DPS), yang diangkat oleh Rapat Umum Pemegang Saham (RUPS) atas rekomendasai Majelis Ulama Indonesia (MUI) ${ }^{16}$. Dewan Pengawas Syariah (DPS) ini bertugas memberikan nasihat dan saran kepada direksi serta mengawasi kegiatan Bank agar sesuai dengan prinsip syariah yaitu prinsip hukum Islam di bidang perbankan syariah yang tertuang dalam bentuk fatwa Dewan Syariah Nasional MUI, termasuk memastikan implementasi tata kelola berbasis syariah. Tugas dan tanggung jawab DPS meliputi ${ }^{17}$ :

a. Menilai dan memastikan pemenuhan prinsip syariah atas pedoman operasional dan produk yang dikeluarkan bank;

b. Mengawasi proses pengembangan produk baru bank agar sesuai dengan fatwa DSN- MUI;

c. Meminta fatwa kepada DSN-MUI

d. Melakukan review secara berkala atas pemenuhan prinsip syariah terhadap mekanisme penghimpunan dana dan penyaluran dana serta pelayanan jasa Bank;

e. Meminta data dan informasi terkait dengan aspek syariah dari satuan kerja Bank dalam rangka pelaksanaan tugasnya.

\footnotetext{
${ }^{16}$ Lihat Pasal 32 UU No : 21 Tahun 2018 Tentang Perbankan Syariah.

17 Lihat PBI No : 11/33/PBI/2018 Tentang Pelaksanaan Tatakelola Perusahaan Yang Baik oleh Bank Umum Syariah dan Unit Usaha Syariah
} 
Apabila melihat tugas dan tanggung jawab DPS diatas, maka dapat disimpulkan bahwa tugas utama DPS hanya memastikan pemenuhan prinsip syariah, baik proses, produk dan layanan, bukan pada pertumbuhan dan pemasaran bank syariah. Mengacu pada kedudukan DPS dalam struktur perbankan syariah, diperlukan jaminan bahwa pengawasan yang dilakukan sesuai dengan tujuan prinsip syariah. Potensi benturan kepentingan dapat terjadi mengingat DPS merupakan bagian dari struktur organisasi bank syariah, yang diangkat oleh RUPS, sementara tugasnya melakukan pengawasan terhadap pengurusan yang dilakukan oleh Direksi. Independensi DPS diperlukan untuk memastikan kepatuhan terhadap prinsip syariah bagi kepentingan seluruh stakeholder dan meningkatkan kepercayaan masyarakat terhadap perbankan syariah. Salah satu cara untuk menghindari benturan kepentingan tersebut adalah memperkuat independensi DPS. Dalam praktik di beberapa negara, struktur DPS akan berkoordinasi langsung dengan unit atau departemen pengembangan produk dan departemen kepatuhan terhadap syariah, untuk memastikan bahwa seluruh fungsi-fungsi bank mematuhi prinsip syariah. Selain struktur DPS, independensi DPS dapat diwujudkan melalui kompetensi anggota DPS, yang dapat dipenuhi melalui kewajiban berikut:

a. Anggota DPS wajib melalui proses sertifikasi yang dikeluarkan oleh lembaga yang ditunjuk. Saat ini tidak ada kualifikasi standar, sertifikasi atau standar akreditasi untuk anggota DPS yang dapat menjamin kualitas dan menjaga perkembangan, termasuk perbankan syariah ${ }^{18}$

b. Anggota dewan pengawas tidak saja menguasai prinsip syariah, melainkan juga menguasai perbankan, dan bidang-bidang lain yang diperlukan untuk pengembangan produk dan layanan perbankan syariah.

c. Proses rekrutmen anggota DPS wajib bersifat terbuka, dan memenuhi persyaratan yang

18 BAPPENAS, Masterplan Arsitektur Keuangan Syariah Indonesia, Cetakan Kedua, (Jakarta: BAPPENAS, 2018), 145. 
ditetapkan, termasuk kalangan akademisi yang bersertifikasi.

Ketiga hal diatas diperlukan untuk mengatasi konsep umum yang keliru bahwa Anggota DPS hanya diwakili oleh ahli syariah saja. Pendekatan yang tepat adalah memasukkan beragam ahli seperti akuntan, manajemen bisnis dan ahli hukum. Saat ini, penetapan anggota DPS mengacu pada PBI No: 14/6/PBI/2012 yang menetapkan uji dasar kelayakan dan kepatutan untuk anggota DPS bank dan Unit Usaha Syariah. Namun demikian, PBI tersebut masih bersifat umum dan tidak secara spesifik menyediakan prosedur yang kokoh untuk penunjukan anggota DPS. Satu hal yang perlu diperhatikan dalam menetapkan standar adalah, pedoman yang digunakan IFSB dan AAOIFI bahwa audit syariah merupakan bagian penting dalam kerangka tata kelola syariah untuk lembaga keuangan yang menawarkan produk dan layanan berbasis syariah.

Selanjutnya, keberhasilan implementasi tata kelola syariah tidak dapat dilepaskan dari peran pemerintah, kesiapan regulasi, pelaku usaha dan masyarakat. Oleh karena itu keberhasilan implementasi tatakelola pada bank syariah akan sangat ditentukan oleh optimalisasi ke 4 pilar ini.

a. Political will pemerintah untuk mendukung dan memfasilitasi industri keuangan syariah menjadi pendorong bagi percepatan pertumbuhan perbankan syariah di Indonesia, mengingat karakteristik pertumbuhan perbankan syariah bersifat bottom up, dibangun dari bawah, sehingga perkembangannya sejalan dengan kebutuhan dan kesadaran masyarakat. Faktanya, pertumbuhan perbankan syariah Indonesia semakin baik seiring dengan perhatian dan keinginan pemerintah untuk memfasilitasi dan mengatur secara baik, termasuk menyediakan kelembagaan yang akan mendukung tumbuh kembang industri perbankan syariah, serta melakukan pengawasan dan penegakan hukum untuk menciptakan industri perbankan yang sehat dan kokoh. Political will pemerintah semakin menguat dengan dibentuknya Komite Nasional Pengembangan Keuangan Syariah Indonesia, kordinasi antara pemerintah dan 
otoritas jasa keuangan. Selain itu, otoritas jasa keuangan mendorong peningkatan kesadara masyarakat terhadap industri keuangan syariah melalui program literasi keuangan dan edukasi masyarakat secara intensif dan berkelanjutan.

b. Regulasi yang kokoh dan penyelesaian sengketa yang tepat, sebagai dasar pelaksanaan aktivitas perbankan syariah yang dapat menjamin kepastian dan perlindungan hukum baik bagi pelaku usaha dan masyarakat. Saat ini perbankan syariah merupakan industri keuangan yang paling siap dari sisi regulasi, dengan diterbitkannya UU No : 21 Tahun 2008 Tentang Perbankan Syariah. Disamping itu, peraturan yang dikeluarkan oleh OJK dan Bank Indonesia yang dibentuk berdasarkan Fatwa DSN-MUI senantiasa mengikuti perkembangan industri perbankan syariah, khsuusnya mengenai pengembangan produk dan akad yang ditawarkan oleh perbankan syariah. Otoritas jasa keuangan telah menyiapkan lembaga yang akan memberikan jaminan dan perlindungan hukum bagi masyarakat dengan menerbitkan 2 POJK, yaitu POJK No : 1/POJK.07/2013 Tentang Perlindungan Konsumen Sektor Jasa Keuangan, yang menganut prinsip transparansi, perlakuan yang adil, keandalan, kerahasiaan dan keamanan data/ informasi konsumen dan penanganan pengaduan serta penyelesaian sengketa konsumen secara sederhana, cepat, dan biaya terjangkau, dan POJK No :1 /POJK.07/2014 Tentang Lembaga Alternatif Penyelesaian Sengketa Sektor Jasa Keuangan, yang bertujuan untuk memfasilitasi penyelesaian sengketa yang cepat, murah, adil, dan efisien. Ke dua POJK tersebut diharapkan dapat menjaga keberlangsungan industri keuangan syariah, dan mendorong naiknya tingkat kepercayaan masyarakat terhadap sektor jasa keuangan syariah, dengan sifat penyelesaian sengketa yang bertumpu pada win-win solution dan kehendak sukarela para pihak. 


\section{c. Kesiapan industri perbankan syariah dalam penyediaan produk dan layanan yang patuh pada prinsip syariah.}

Berdasarkan data, hingga tahun 2016, jumlah pelaku perbankan syariah terdiri dari 13 Bank Umum Syariah (BUS), 21 Unit Usaha Syariah (UUS) dan 163 Bank Pembiayaan Rakyat Syariah (BPRS) dengan 2.163 jaringan kantor BUS dan UUS, sementara market share perbankan syariah baru mencapai $4,81 \%^{19} \cdot$ Kondisi ini tentu masih jauh dari target optimis yang sudah dicanangkan sejak diluncurkannya UU Perbankan Syariah. Bahkan berdasarkan data yang dikeluarkan OJK, perbankan syariah mengalami perlambatan pertumbuhan sejak tahun 2014, dari market share 4,85\% menjadi 4,83\% ditahun 2015 . Sementara itu, tingkat global, Indonesia memperoleh pengakuan inernasional sebagai pendorong keuangan syariah di masa depan. Oleh karena itu, diperlukan upaya-upaya untuk mendorong percepatan pertumbuhan perbankan syariah guna memanfaatkan peluang global. Pemerintah sudah mempersiapkan infrastruktur hukum dengan menerbitkan roadmap perbankan syariah nasional 205-2019 yang berisi rencana pengembangan sektor perbankan syariah yang megacu pada Masterpan Sektor Jasa Keuangan Indonesia, dan secara khusus telah menerbitkan Masterplan Arsitektur Keuangan Syariah Indonesia, yang dapat menjadi referensi bagi stakeholder perbankan syariah dalam pengembangan industri perbankan syariah.

Berikut kebijakan yang dapat mendorong perubahan persepsi dan menaikkan tingkat kepercayaan masyarakat baik langsung maupun tidak langsung

\section{Arah kebijakan perbankan syariah}

\begin{tabular}{|l|l|l|}
\hline No & Arah Kebijakan & \multicolumn{1}{|c|}{ Tujuan } \\
\hline 1 & $\begin{array}{l}\text { Memperkuat sinergi } \\
\text { kebijakan antara otoritas } \\
\text { dengan pemerintah dan } \\
\text { stakeholder lainnya }\end{array}$ & $\begin{array}{l}\text { Optimalisasi dukungan terhadap industri } \\
\text { perbankan dan keuangan syariah }\end{array}$ \\
\hline 2 & $\begin{array}{l}\text { Memperkuat permodalan } \\
\text { bank dan skala usaha serta } \\
\text { memperbaiki efisiensi }\end{array}$ & $\begin{array}{l}\text { Ekspansi dan mengubah persepsi bahwa } \\
\text { perbankan syariah diperuntukkan bagi segmen } \\
\text { atau ukuran pasar tertentu }\end{array}$ \\
\hline
\end{tabular}

19 Departemen Perbankan Syariah , Roadmap Perbankan Syariah Indonesia 2015-2019, (Jakarta: Otoritas Jasa Keuangan, 2018), 12. 


\begin{tabular}{|l|l|l|}
\hline 3 & $\begin{array}{l}\text { Memperbaiki struktur dana } \\
\text { untuk perluasan segmen } \\
\text { pembiayaan }\end{array}$ & $\begin{array}{l}\text { Pemberian poris berimbang pada segmen } \\
\text { komersial dan korporasi, serta dukungan } \\
\text { aktivitas perdagangan lintas negara }\end{array}$ \\
\hline 4 & $\begin{array}{l}\text { Memperbaiki kualitas dan } \\
\text { layanan produk }\end{array}$ & $\begin{array}{l}\text { Antisipasi kecenderungan yang } \\
\text { mempengaruhi pengembangan produk ke } \\
\text { depan }\end{array}$ \\
\hline 5 & $\begin{array}{l}\text { Meningkatkan kualitas dan } \\
\text { kuantitas sumber daya } \\
\text { manusia, teknologi } \\
\text { informasi serta infrastruktur } \\
\text { lainnya }\end{array}$ & $\begin{array}{l}\text { Mendorong keberhasilan pengembangan } \\
\text { perbankan syariah, terutama untuk } \\
\text { menghasilkan produk dan layanan yang sesuai } \\
\text { dengan ekspektasi masyarakat } \\
\text { preferensi masyarakat dan }\end{array}$ \\
\hline 6 & $\begin{array}{l}\text { Memperkuat } \\
\text { harmonisasi pengaturan dan } \\
\text { pengawasan }\end{array}$ & $\begin{array}{l}\text { Meningkatkan literasi atau pengenalan } \\
\text { masyarakat terhadap produk, akad dan } \\
\text { layanan perbankan syariah }\end{array}$ \\
\hline 7 & $\begin{array}{l}\text { Menjawab perubahan dan dinamika } \\
\text { perekonomian global, menciptakan fairness } \\
\text { untuk pelaku industri, serta lebih harmonis } \\
\text { dalam pengaturan yang bersifat cross } \\
\text { sectoral. }\end{array}$ \\
\hline
\end{tabular}

Sumber : Roadmap Perbankan Syariah Indonesia 2015-2019

\section{Kesimpulan}

Berdasarkan pemaparan diatas, maka dapat disimpulkan hal-hal sebagai berikut:

1. Pertumbuhan perbankan syariah Indonesia mengalami perlambatan yang diakibatkan oleh beberapa isu strategis, diantaranya rendahya kuantitas dan kualitas sumber daya manusia yang mampu memastikan kepatuhan terhadap prinsip syariah, serta mispersepsi dan rendahnya tingkat kepercayaan masyarakat terhadap produk dan layanan perbankan syariah.

2. Implementasi tata kelola merupakan hal penting dalam industri perbankan syariah untuk memastikan kepatuhan terhadap prinsip syariah guna mencapai tujuan akhir perbankan syariah, serta menjamin kepastian dan perlindungan bagi bank syariah dan masyarakat.

3. Implementasi tata kelola yang terintegrasi melalui fungsi pemerintah dan otoritas, kesiapan infrastruktur legal, peran Dewan Pengawas Syariah dan tingginya tingkat pemahaman masyarakat, dapat mendorong percepatan pertumbuhan perbankan syariah Indoonesia. 


\section{Daftar Pustaka}

Ahmad, Jahanara Sajjad. Corporate Governance in Islamic Banks, Hawkamah The Institute for corporate governance, Juni, 2018

Asutay, Mehmet. An Introduction to Islamic Moral Economy, United Kingdom: Durham Islamic Finance Summer School, 2013

BAPPENAS. Masterplan Arsitektur Keuangan Syariah Indonesia, Cetakan Kedua, Jakarta: BAPPENAS, 2018.

Departemen Perbankan Syariah, Roadmap Perbankan Syariah Indonesia 20152019, Jakarta: OJK, 2018.

Ethica Institute of Islamic Finance, 2017, Handbook of Islamic Finance, 2017 Edition

Luqman, Nurhisam. Kepatuhan Syariah (Sharia Compliance) Dalam Industri Keuangan Syariah, Jurnal Hukum IUS QUIA IUSTUM Vol.23 No.1, HIm.78. , 2016

Mohamad Hussain, Madzlan. Corporate Governance Of Institutions Offering Islamic Financial Services (IIFS): An insight of the Islamic Financial Services Board's Initiative, Aman Jordan: IIFS,2005. Perry, Frederick V. The Corporate Governance of Islamic Bank: A Better Way of Doing Business?, Michigan State: Journal of International Law, Vol.19:2, 2018.

Otoritas Jasa Keuangan. Booklet Perbankan Indonesia 2016, Edisi 3, Jakarta: OJK, 2016.

PBI No : 11/33/PBI/2009 Tentang Pelaksanaan Tatakelola Perusahaan Yang Baik oleh Bank Umum Syariah dan Unit Usaha Syariah (Lembaran Negara Republik Indonesia Tahun 2009 Nomor 175DPbS)

Saidi, Nasser. Corporate Governance in Islamic Finance, Hawkamah, The Institute for Corporate Governance

Undang-Undang No : 21 Tahun 2008 Tentang Perbankan Syariah (Lembaran Negara Republik Indonesia Tahun 2008 Nomor 94 dan Tambahan Lembaran Negara Republik Indonesia Nomor 4867) 